\title{
Reading Ascension: Intertextuality, Improvisation, and Meaning in Performance
}

\author{
Jeremy Strachan
}

\section{Introduction}

In 2007, I organized a performance of John Coltrane's iconic 1965 work Ascension in Toronto, Canada. As a way of commemorating Coltrane's legacy, the performance was also a chance for me to reaffirm my connection to Toronto's thriving improvised music scene. I was at the time living in St. John's, Newfoundland, having moved there for graduate studies in ethnomusicology, and I was feeling acutely detached from the practice of improvisation, and music-making in general. By the late-2000s, I had been performing frequently as a saxophonist in various creative music groups in Toronto in addition to regularly appearing in concerts of improvised music with ad hoc ensembles, and not long after my relocation to St. John's I found myself again eager to play. I returned to Toronto for the summer, and in July, I led an eleven-piece ensemble through a forty-minute performance of Ascension at the Tranzac, a well-known venue for creative music in the city. In the intervening years between 2007 and now, I have been asked to organize performances of Ascension several times: in 2008, 2010, ${ }^{1}$ and most recently in 2012 as part of the Guelph Jazz Festival. And, in January of 2013, I was interviewed for a six-hour radio documentary on Ascension produced for KJFC-FM, which aired in May of $2013 .{ }^{2}$ This is all to say that I have found myself associated with Coltrane's work in a way I did not anticipate in 2007.

Ascension has held the interest of critics and musicians nearly five decades on for its overwhelming resonance as an avatar of improvisation's social and spiritual potential. Its resilience as a work is manifest in the performances it continues to receive each year around the globe, ${ }^{3}$ despite the obvious practical and musical demands it presents. Commentators remain divided on its efficacy as a musical statement. It has continued to elicit superlative statements: called "the most powerful human sound ever recorded" in Bill Mathieu's often cited Downbeat review, it has also been described as a "mystical text" for some listeners (Ake 33). As Michael Dessen writes, Ascension is a "radically heterogeneous kind of large scale group improvisation with the notion of music as a spiritually transformative process" (178), and one that has been "long misunderstood" (Jenkins); Eric Nisensen, one of Coltrane's numerous biographers, boldly castigates it as "ultimately, a failure." He writes, "An audacious failure-even fanatic Coltrane haters [...] at least agreed about the saxophonist's sheer audacity in recording a piece of music like Ascension" (173). Nisensen feels Ascension becomes, over the course of its 40 minutes, a "numbing" listening experience (174). Nonetheless, he writes that Ascension was "a noble attempt to put the sounds of the New Thing into a large musical setting," and works as an announcement of Coltrane's allegiance with the avant-garde in jazz (174). In its ambition to expand in size and length the possibilities of structured improvisation, which Coltrane had been pursuing with his classic quartet during the mid 1960s, Ascension stands (along with 1964's A Love Supreme) on a line of demarcation, separating "late-period" Coltrane from what came before.

Performing Ascension comes with a set of heightened expectations, and there is a mythos surrounding the composition that sets it apart from other works - it is, as saxophonist Glenn Spearman comments, the "Handel's Messiah" of jazz. ${ }^{4}$ In this paper, I want to focus on how musical relationships are indexed in "reading" and performing Ascension by examining intertextuality in improvisation. I begin with a brief explication of (inter)textuality and Ingrid Monson's idea of intermusicality, which considers the social aspects of intertextuality in performance. In bringing musicians' accounts from our 2007 performance to bear on my own observations from subsequent performances, an intertextuality emerges between those performances and Coltrane's original 1965 recording that is primarily historical (Klein 12). Using interviews conducted in 2008 with several musicians in the ensemble, I illustrate the discrepant and heterogeneous interpretations of that concert, which attenuate Ascension's symbolic power as a utopian expression of community. In performance Ascension is a gathering space that affords a kind of heightened musical sociality, yet it also highlights the textual "irreducibility" of group improvisation that resists unified readings (Barthes 160). The final section of this essay is partly autoethnographic, where I locate myself within the experiential purview of performer as well as analyst. Staging repeated performances of Ascension has chronicled and dynamized musical networks as they exist(ed) between myself and other musicians. As such, I consider these various Ascensions as textual objects that speak to each other, whose relationality historicizes improvisation and also materializes tensions between musicians and the politics embodied in group improvisation.

\section{Intertextuality}

In deconstructionism and poststructuralism the term textuality marks both a breakdown of the boundaries between literature and other verbal and non-verbal signifying practices, and the subversion of the principle that any text can function as an object whose meaning is coherent and self-contained. Textuality thus describes the tendency of language to produce not a simple reference to some external coherent structured world outside the language, but a 
multiplicity of potentially contradictory signifying effects that are activated in the reading process (Jones 641). Terry Eagleton, commenting on Roland Barthes' emphasis on the value of "writeable" works, notes how a critic "can carve them up, transpose them into different discourses, produce his or her semi-arbitrary play of meaning athwart the work itself" (137). Text is diffuse, an

inexhaustible tissue or galaxy of signifiers, a seamless weave of codes and fragments of codes, through which the critic may cut his own errant path [...] If there is any place where this seething multiplicity of the text is momentarily focused, it is not the author but the reader. (138)

As he elaborates in the seminal essay "From Work to Text," Barthes compiles a range of qualities that a text possesses: it is above all, a malleable thing; a "methodological field," one that reveals itself to be a "process of demonstration" that is "experienced only in an activity of production" (157). Text is dilatory (158), in that there is always a process of dilation of meaning, a result of what Barthes calls text's "stereophonic" and "stereographic plurality" $(158,160)$. Barthes considers text in terms of its spatial dimension, its fundamental heterogeneity, but also its sensory implications-which appeal to both visual and auditory perceptual faculties. Drawing a connection to music, he writes,

We know that today post-serial music has radically altered the role of the "interpreter," who is called on to be in some sort the co-author of the score, completing it rather than giving it "expression." The Text ${ }^{5}$ is very much a score of this new kind: it asks of the reader a practical collaboration. (163)

Scholars of music such as Ingrid Monson (Saying Something), Bennett Hogg ("Enactive Consciousness"), and Michael Klein (Intertextuality) have borrowed from literary theory in thinking about music's textuality, as a way of tracing networks between composers and performers as they stretch across expanses of time and space. Texts, according to Kristeva, are always a "permutation" of other texts "intersecting and neutralizing one another" (36), and are thus already intertextual. Music's materials are similarly always already intertextual, in that melodic, harmonic, rhythmic, and timbral resemblances between musical texts generate an intertextual relationality between musical works, either by intent or coincidence. Indeed, jazz improvisation coheres around notions of intertextuality: citational practices of melodic quotation, the palimpsestic nature of contrafacts, alterations, and chord substitutions attest to a methodological prerogative in jazz performance that foregrounds its fundamentally dialogic character.

Ascension itself is compositionally intertextual. It begins with an ascending three note motive in B flat minor, played first in the saxophones and taken up loosely by the rest of the ensemble. The three-note blues motive closely resembles the bass ostinato in "Acknowledgement" from Coltrane's 1964 suite A Love Supreme:

(see Figure 1).

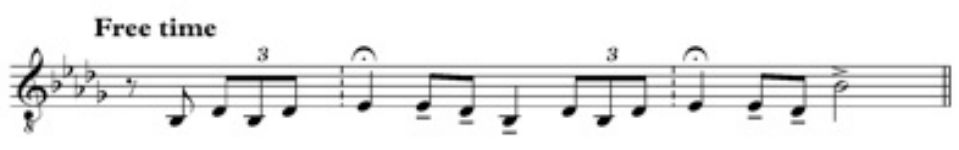

Fig. 1: Opening motive from Ascension played by tenor saxophones and trumpets.

(see Audio Example 1). ${ }^{6}$

(see Figure 2).

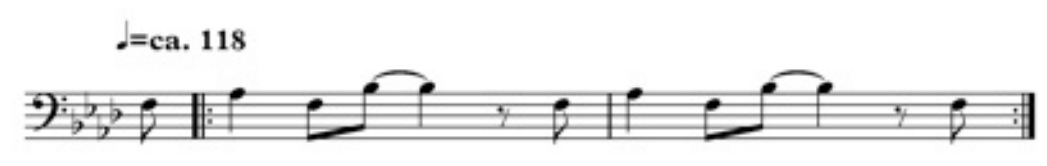

Fig. 2: Bass ostinato from opening of A Love Supreme, "Acknowledgement."

In that piece, Coltrane takes the motive through all twelve key areas at an emotionally pivotal part of the movement. Following his solo, he uses that three note cell as a means of exploring gradients of harmonic tension, by imposing dissonant juxtapositions over the static bass ostinato. Lewis Porter calls this a brilliantly executed "reverse 
development," where Coltrane "saves the exposition—or perhaps 'revelation' would be a better word in this case-for the end. He's telling us that God is everywhere-in every register, in every key-and he's showing us that you have to discover religious belief [...] As we listen to the music, its meaning unfolds for us" (John Coltrane 242). The ties between A Love Supreme and Ascension via this motive have been observed by Porter ("Liner Notes" 8), Ekkehard Jost (88-90), and more recently by Marc Howard Medwin (103), who all highlight its symbolic resonance as a musical image-one that invokes the former work's meditative and spiritual implications. As I discuss below, this motive became an important textual component of Ascension for some of the musicians in my ensemble.

Intertextuality constitutes performance practices in creative music, in that musicians display historical knowledge, situational competency, and sonify relations between performers and listeners by bringing aspects of musical textuality into proximity through aural gestures: a quoted fragment from a famous solo, a particular timbral coloration, a thread of a recognizable composition woven into the fabric of an improvisation brings performances into dialogue with each other. Ingrid Monson calls this intermusicality, a word "best reserved for aurally perceptible musical relationships that are heard in the context of particular musical traditions" (128). Monson's important concept accounts for how any given group of listeners will comprise a widely inconsistent cross-section of interpretive competence, familiarity, and intertextual facility in identifying how musical gestures relate to each other in the listening experience. Intermusicality is also a practical formulation, and not merely a theoretical construction, in that musical communication is primarily social. Whereas intertextuality for Monson veers towards the syntactic and formal dimension of textuality, intermusical exchanges imbricate the communicative potential of improvisation (129). As Bennett Hogg writes, sound does not carry meanings in and of itself; rather sounds are "the sites of complex and mediated sets of relationships between physical sounds, perceptual systems, personal associations, culturally signifying gestures, bodily and emotional responses, observed actions and reactions, and culturally learned listener expectations" (88). Like Barthes' stereophonic plurality, a musical text resonates with an irreducible heterogeneity that becomes manifest in the listening and (if performed live) playing of it.

Yet, Monson also suggests that jazz performances "are not musical texts in and of themselves (in that they are negotiated between multiple improvising participants), but when such performances are recorded and disseminated [...] they become texts" (126). My use of text differs slightly from Monson's in this regard. Folklorist Jeff Todd Titon defines a text as "any interpreted object, verbal or otherwise" (70), which is useful to this discussion in several ways. A text is something that principally beckons an interpretation; it is an object, suggesting the existence of textual boundaries, which linguist William Hanks argues are precisely what separate text from non-text (104).

Performances-specifically cultural performances (Singer 71-72) - satisfy these criteria, as bounded and formal systems of communication involving performers, audiences, and performance spaces. A text's repeatability, mutability, and persistence across generations within a particular community are central to its teleology. Titon elaborates that "the instability of a folkloric text is the result of its emergent and processual character, stressing the dialectic of innovation and tradition within community-based expressive culture and the relations between performer and audience" (73). Monson also notes the tension between innovation and tradition that exists in jazz performance embodied by quotation and allusion, sonic markers that engender relationality in improvisations (97). Yet the two countervailing (or perhaps complementary) forces of tradition and innovation are what bind improvised musical performances to their histories; they simultaneously affirm musical lineages and direct historical ties to previous generations of practitioners, while pushing that tradition forward through pressuring the ambit of performance practice. Hanks considers this aspect of textual location and interpretation:

The fact of interpretability by a community of users locates text not so much in the immanent structure of a discourse as in the social matrix within which that discourse is produced and understood. It also signals a social orientation according to which text, whatever else it is, is a communicative phenomenon. (96)

Read through Hank's proposition that text is above all communicative primarily as a social phenomenon, the interpretative variability of the performers as listeners which I examine in the following section illustrates multiple and contrasting social orientations that work together in complex ways. I would thus propose that our performances of Ascension under discussion here are to be considered within the analytic lens of (inter)textuality in examining its historicizing effects on improvisational practices. Michael Klein observes that musical intertextuality takes on various forms as musical works "intersect" with each other in different ways, and that calling music intertextual warrants a more specific nomenclature. Musical intertextuality can be aesthetic, poeitic, or aleatoric; pertinent to the present study, it can also be historical or transhistorical (12). I am suggesting that contemporary performances of Ascension are both historically and transhistorically intertextual, in that they instantiate the original recording's historicity, but also bring to bear the distance separating us (as listeners and performers) from it. More than simply playing Coltrane's composition as a tribute, some musicians in my ensemble traced sonic alliances with the work through improvisation, creating a sense of renewed closeness with Ascension and Coltrane; for others, as I will show below, improvising within the structure of Ascension had nothing to do with 1960s free jazz, Coltrane's symbolic power, or the work's legacy. 


\section{Listening to Ascension}

Unbeknownst to many of us (including myself) at the time, a recording was made of our performance at the Tranzac in 2007, which I subsequently obtained and used during interviews with the members of the ensemble in late winter of $2008 .^{7}$ My prime initiative was to discuss the players' individual solos and the interaction between soloist and the rhythm section. I approached this process with a set of my own assumptions and biases: I anticipated that the nature of our conversations would centre on the emergent social relationships within an improvising group, on the exchange of gestures, and how the balance of power amongst players is negotiated during improvisation. These preconceptions were formed largely by my familiarity with theoretical and ethnographic scholarship that has accented the phenomenology and ontologies of improvising (Bailey; Benson; Berliner; Borgo "Synergy," Sync; Corbett) and the intersubjectivity of real-time music-making I have experienced as an improviser.

While this indeed happened, listening to the recording revealed crucial and interesting disjunctures in memory and interpretation. Further, the heterogeneity of interpretation, set against Ascension's narrativity as a composition and its symbolic, even spiritual importance in the history of avant-garde jazz, reveals deeper, often contrasting layers informing our improvisations, and points to a multiplicity of coexistent intentions, actions, and responses dynamizing the performance. In discussing our performance of Ascension, many of the musicians acknowledged that we were entering into a context for improvisation that had very clear musical and extramusical parameters, one which valorizes innovation alongside reverence to tradition.

The assumed boundaries, which the work imposed regarding our style of improvisation, were indeed clear to several musicians, as was the work's location along an aesthetic continuum of soloistic virtuosity and individual expression. Briefly, the structure of Ascension is relatively straightforward, and its harmonic and melodic materials are loosely built around changing modal regions containing scalar fragments that are distinctly perceivable on the original 1965 recordings. Its form oscillates between ensemble passages-the full battery of five saxophones and two trumpets playing atop the rhythm section of piano, two basses and drums-and individual solos. Tenor saxophonist Colin Fisher, the first to solo after the opening head and ensemble section of the work, told me his solo was informed by Coltrane's expanded modal improvising during the period in which Ascension was recorded. One of the first comments he made during our interview was how hard it was to separate himself from the historical context of the piece. ${ }^{8}$ His solo begins with rapid runs and medium-length phrases, and then switches to reed-biting, multiphonics, and other gestural extended technical devices, before returning to breath-length cascades of descending figures (see Audio Example 2). All of these textural elements are common to the era of 1960s free jazz: this style of improvising prioritizes ornate modal invention, extreme harmonic abstraction, and the timbral and coloristic characteristics of instruments without abrogating the established roles of each instrument within the jazz tradition. Colin mentioned that he had been listening to this piece since he had begun improvising as a musician, and felt a strong obligation to improvise motivically and harmonically within Ascension's compositional purview, rather than blowing totally free.

Jason Hay, also playing tenor, confirmed that his solo—comprised of almost exclusively extended technical playingwas directly informed by Coltrane's Ascension. Jason uses a technique of flutter tonguing in his solo, combined with a very tight embouchure and false fingering, which produces a bird-like cry in the horn's altissimo register (see Audio Example 3). At the time of the concert I believed him to be playing in the style of Pharoah Sanders. He affirmed that he was indeed doing "that Pharoah thing," and told me "there is always going to be that reference point back to the original," but also that he did not want to "tread over the same ground." The energy of Jason's solo and the intent behind it was a direct response to the contextual implications of Coltrane's original piece. As I discuss below, this was not the case for every musician.

For Colin and Jason, this connection to Coltrane and the significance of Ascension as being an instructive text in their own development as improvisers dictated the stylistic and emotional boundaries they felt were appropriate in which to frame their performance. Both of them, however, also identified the need to assert their individuality as improvisers. Jason said that although he was improvising according to a specific set of aesthetic conditions, he wanted to hear himself, to hear his voice as an improviser. Similarly, Colin told me that despite the imposing historical context, he did not have to "think too much," and just tried to be himself, to pursue an improvising strategy with which he felt most comfortable - a balance of motivic soloing and extended techniques. Stylistically, Colin's and Jason's playing was striking in how it matched the respective tenor saxophone solos of Coltrane and Sanders on the 1965 recording. But both players also felt a commitment to their craft that went deeper than just replicating Coltrane's expanded modal playing or Sanders' energetic overblowing, revealing an allegiance to 1960s free jazz that recuperates its "traditional" musical materials-what Monson calls its sound worlds (125) —as well as its valorization of innovation.

Drummer Brandon Valdivia, perhaps more than Colin and Jason, took Ascension to be a "mystic text," and approached the performance with considerable gravity due to the work's spiritual connotations. "I remember thinking [...I was just] trying to be serious," he recalled, and the spirituality surrounding the work affected him in a way he 
"didn't really understand."

This aspect of Ascension affected players in very different ways, but Brandon's emotional connection to the work resulted in powerful playing even though it bore little stylistic resemblance to Elvin Jones' polymetric Afro-Latin drumming. Bassist Mike Smith recalled: "For me, in terms of the spiritual content, I take that as a level of intensity that's going to come out-how I perform. Where that's coming from isn't as important to me [...] I definitely, especially in this piece, I tried to take it from the musical perspective from, say, Jimmy Garrison, or another bass player of the time, rather than really playing like I would do anything else."

Alto saxophonist Brodie West (who I interviewed in the same session as Brandon and Mike) noted that performing this kind of free jazz, stylistically rooted in 1960s black expressive culture, exposes problematic issues of race, politics, and cultural ownership. ROVA member Bruce Ackley recounted how their recording of Ascension in 2002 could have been seen as treading on hallowed territory, violating the sanctity of Coltrane's piece and appropriating a fundamentally black art form: "I didn't feel worried about what other people would think. I think that there probably are some dissenters too, but that's OK [...] This is a sacred piece of music that it is just as much ours as it is anybody else's. It doesn't belong to anybody. We're going to celebrate" (Jung).

In our conversation, Brodie and I discussed the potential criticism we might have received about playing a composition that has been seen as isomorphic with the 1960s Civil Rights Movement in the United States, spiritual universalism, and political unrest in American culture-as Eric Nisensen writes, "one can argue that in Ascension one can hear the aesthetic of the race riots. It undoubtedly belongs in a Sixties time capsule, since it so perfectly captures much of the furious tempers of the times" (175). Coltrane's music has long been imbricated within a wider discussion about race and politics of the 1960s, and scholars have vigorously debated where both Coltrane and free jazz at large sit with respect to the Civil Rights and the Black Arts Movements. Examples abound locating Coltrane within this discourse, albeit ambiguously. Lorenzo Thomas discusses music's role in the growth of the Black Arts Movement, and notes how writers such as Amiri Baraka, Kalamu ya Salaam (and others) viewed Coltrane as a key figure in their attempts to reclaim an ideological prerogative over jazz (258). Composer Anthony Davis, discussing his 1986 opera X (about the life of Malcolm X) calls Coltrane "the link" between Malcolm X and music: "he symbolized musically what Malcolm symbolized on a social level—-the intersection of the spiritual and the political" (Davis 45). Frank Kofsky positioned Coltrane as a revolutionary figure in this regard, despite Coltrane's refusal to cast his music in explicitly political terms. Kofsky notes that "Coltrane never fully immersed himself in the heady and swirling currents of the political black nationalism of the 1960s-that simply was not his style," and also cautions readers that he was not in "any overt sense" a black nationalist (418). Yet he does consider Coltrane's music as a space of conflict where writers and listeners were forced to make a choice between pursuing a direction towards black nationalism, or retreating from it—a split that weeded out "the musically militant sheep from the liberal lambs" (418).

Yet, contra Kofsky (and Nisensen), Mark Gridley has forcefully addressed the problematic (and often inaccurate) connections that have been made between music and the sociopolitical climate of 1960 s America. He notes that such comparisons not only operationalize a false homology between practices of black jazz musicians working within the fields of "avant-garde" or "free" jazz and contemporaneous political currents, but that they also commit a great disservice to the creative dimensions of improvisation and composition. Gridley suggests that these correlations are nothing short of "illusory" and pose a pedagogical danger to the study of jazz in both its practice and as cultural history (152).

While preparing for our performance of Ascension, and in subsequent interviews, these issues nonetheless lingered in the background. By comparison, Brodie talked about a performance of the Peter Brötzmann Ensemble at the 1985 Vision Festival in New York City. ${ }^{9}$ Brötzmann's group featured fellow European Peter Kowald, as well as black free jazz luminaries Charles Gayle, Jemeel Moondoc, David S. Ware, William Parker, and Rashied Ali. Brötzmann and Kowald were "screaming for a different reason," Brodie said, implying that free jazz's emergence from the social, political, and historical matrix of the 1960s was delineated also along lines of race; Brötzmann and Kowald could only be "coming from different worlds" as Europeans. Tellingly, Brodie said, "it might be surprising" for people to know that he "wasn't thinking that much about Coltrane" during the 2007 performance of Ascension.

Bruce Ackley's claim that the music "doesn't belong to anybody" minimizes the historical contingency and cultural contexts of Ascension's provenance as an original performance, but it also highlights an important aspect of the work's intertextuality. While Ascension was chiefly meaningful for Colin, Jason, Brandon, and myself precisely because of its explicit connection to 1960s free jazz and Coltrane's spiritualism, it has equally become a site for musicians to encounter the work and its particular energy without being moored to such specificities. Brodie told me:

You can interpret the sound however you want [...and] it can be a bit alienating I guess. It's a performance with a certain religious motivation [I] can't relate to. If you're hearing good music it doesn't matter. As far as 
approaching this piece, it was really like another composition. It really seemed like a good way of getting a bunch of people together to do something.

Brodie described Ascension's opening three-note motive (Figure 1) as the call, "just a way for everyone to say, 'Are you here? Yeah I'm here. OK, let's go." Mike agreed, saying it was like a "call to performance. It really is a call to bring everyone together to play." Brodie continued: "It's a composition where everyone starts right away [...] You'd think it's not sophisticated, like maybe what a large group could be otherwise used for," adding, "It is like a communal thing. The way it's written is interesting." Ekkehard Jost, in an early analysis of the work, comments:

In Ascension, the formal disposition into collective improvisations and solos has a second framework superimposed on it, which is a source of structural differentiation, especially during ensemble passages. It consists of systematic changes of modal levels, and occurs with only slight deviations in all eight collective improvisations [...] In many parts, modal scales "show through" rather than being palpably present. (87)

He acknowledges that the piece is largely made up of passages of dissonant complexes that permit only "guesswork" as a modal focus (88). In Jost's reading Ascension is about the sublimation of the individual voice of each player in the texture of the whole, as each musician works to contribute to changing "sound fields." He says, "Quite plainly, the central idea is not to produce a network of interwoven independent melodic lines, but dense sound complexes" (89). The unchanging nature of the cellular material and its treatment by each player contributes to a structural rather than soloistic or expressive part of the work, and Jost is not convinced that Coltrane wanted his musicians to stand out as individuals. Mike Smith observed (of our performance): "It's amazing though. With such a large group, it sounds a lot more together than the same thing if you had a quartet coming out full strength like that. I think it would sound a lot more chaotic than it does with ten people, maybe because it all joins together as one texture. You can hear individual voices coming out, but it's certainly not as easily audible."10

In this analysis, the compositional prerogative of Ascension stands out as an ideal platform for possible associative meanings, such as equality, unity, and collectivity. Further, it speaks to a resistant impulse against melodic individuality and levels out the established musical hierarchies in jazz typically defined by a dominant melodic voice supported by secondary harmonic and rhythmic elements. During ensemble sections the seven horns-five saxophones and two trumpets—coalesce into nebulous harmonic fields rather than articulating discernible melodic statements, layering waves of sound on top of the foundational pulse of the augmented rhythm section of piano, drums, and two basses. So the "call" that Brodie and Mike heard in the opening motive, more than just a melodic fragment, signals a symbolic awakening into collective musical action, and a dissolution of ego, into a holistic sound world.

The spiritual connotations of Ascension's opening motive and its transformations have clear connections to the pervasive religiosity dominating Coltrane's late music. As a three-note figure, it is perhaps a referent to the Holy Trinity, as Coltrane's compositions after A Love Supreme are frequently given titles alluding to religious, mystic, and transcendent themes. ${ }^{11}$ Also, the movement through harmonic regions in Ascension's structure possibly holds numerological significance. David Glen Such identifies the four main modal centres governing the ensemble sections in Ascension as B flat Aeolian, D Phrygian, G flat Lydian, and F Phrygian (57-58). ${ }^{12}$ Each of the first three of these modes is a major third apart: taken as an aggregate, these tonic pitches outline an augmented triad-a chord containing three possible roots depending on its enharmonic orientation, implying multiplicity, unity, and equality. The $\mathrm{F}$ anchors the overall harmonic scheme by tonicizing $\mathrm{B}$ flat and continually signaling a return to the beginning of the form, which suggests perpetuity, cyclicality, and renewal.

Jason, Colin, Mike, Brandon, and Brodie all acknowledged to varying extents that Ascension's spiritual energy resonated with them, but as the foregoing discussion implies, their performances hinged on many other associative factors. Keyboardist John Kameel Farah, however, professed to having no familiarity with the piece-as did trumpeter Lina Allemano-and the spiritual had little or no effect on how they approached their performances. John, a wellrespected and classically trained pianist and composer, told me that for him, Ascension appeared to be in rondo form: A B A C A D A, etc., in which each A section represents the ensemble return, and the changing $B, C, D$ sections gave soloists a space to elaborate that material. John's reading of Ascension, as he described it to me, was ultimately formalist in that his background as a composer and student of Western art music foregrounded the compositional topography of the piece over emotional or cultural attachments. In talking about his experience soloing, after comping under all of the other horn players' solos, he recalled: "Suddenly that thing that you had been responding to [their solos], that has been your work of art, is gone." John used the evocative image of a dancer being held aloft by another, and said:

As a soloist, suddenly you are being propped up [...] Suddenly you feel the ground stops for a second and [you think] "what are you going to do?" And there's no force behind you propelling that wave [...] As a 
composer I am very into structure and being intelligible and cohesive no matter what the language is or how abstract it is. Everything I had played so far I felt was very logical and emotional and structured.

After listening back, John likened his solo to a tidal wave that dissipated rather than crashed into the next section of the improvisation (see Audio Example 4). He was surprised by the audience reaction, and critiqued the compositional arc of his solo: "Where is the structural cohesion to propel it into the next solo? For [the other solos] I felt as though I was the one who had provided that."

Trumpeter Lina Allemano listened to her solo in Ascension, and after about 20 seconds, remarked, "Well, it's not a great solo." She said the volume of her playing stayed constant, which "was dumb, in retrospect," and that her solo was "sort of just the same thing" over and over. She did not enjoy listening back to her own solo during our interview and explained that it was not reflective of her skills as an improviser. There were other reasons she offered as explanations of why she felt her solo was unsuccessful: she said she might not have had "her chops," or perhaps was tired, or felt the pull of competing with such a large ensemble. Interestingly, she remembered her solo as being preceded by "lots of music," and thought her solo came much farther down in the order than it actually did. When I corrected her and told her that she was only the second soloist, she was visibly surprised. The element of fatigue, which she "heard" in the recording of her solo, was based purely on a textual interpretation, not an experiential one. My reading of Lina's playing, both on the recording and during the actual concert, was much different-I heard an incredibly focused performance. She was indeed "doing one thing over and over again" but I attributed that to a structural goal, an intentional improvisational decision that was consciously made. This was partially based on my knowledge of Lina as a respected professional jazz musician, and as a highly skilled improviser. ${ }^{13}$ As a conductor, I let her play for a long time before cueing the band back in. I was enjoying her performance and the interaction between her and the rhythm section, so I let the improvisation unfold for longer than I did with other soloists.

During Brodie's solo, which unlike Lina's, did come quite late in the piece, I felt that something was amiss. Brodie was making excessive use of negative musical space, and the dynamic level of the improvisation dropped considerably. ${ }^{14}$ At the time, I interpreted Brodie's playing as being marred by indecision and hesitation. Quite simply, I thought he was struggling. When I cued the band back into play, Brodie was still soloing and playing off the wave of energy that the re-entrance of the ensemble generated. But later, Brodie told me he was consciously trying to alter the course of the performance:

I wouldn't take responsibility for it as a solo. I kind of think of it not as a solo. I wanted to bring the focus to a group improvisation...by breaking it up so much. Now we have a different relationship as players. I would have [played more aggressively] if it was at the beginning of the piece. It was a crucial point strategically if you think about it as a structure. (see Audio Example 5)

Had I been able to pick up on that as a conductor, I would not have cut off his solo so soon. Both Colin and Lina readily acknowledged in interviews that they could tell Brodie's strategy was to refocus the improvisation to a group dynamic —not soloist and rhythm section, but an equal four part texture (drums, bass, keyboard, saxophone)—which is indicative of their more profound knowledge of Brodie's musical personality. His use of space and the unsaid was in fact quite deliberate. Brodie continued to explain his solo: "I definitely can't say what I did; you're in the middle of a long piece and lots has happened already. I hadn't made a conscious decision, but I did feel like that plays a big role relationally to the rest of the piece."

\section{Conclusion: Ascension's (after)text}

Even amongst the "seething multiplicities" of meaning that emerged in my interviews with performers of Ascension, we all shared in an experience which has stayed with us far beyond the performance as a text in and of itself. John Kameel Farah spoke in evocative poetic metaphors, how we as performers were dipping like swimmers into a "river of history"; Mike Smith, who (with Brandon) anchored the entire performance, was surprised to hear the brevity of his solo, and the vexatious uniformity of phrase lengths: indeed, for many the "inner" time and "outer" time that musicians experience as part of the phenomenology of performance was a recurring point of discussion. ${ }^{15}$ For myself, the communal importance of doing Ascension and the regenerative action of bringing together a large group of musicians to celebrate and attest to the symbolic resonance of John Coltrane was crucial. Ascension's aftertext, or "the constellations of consequences and outcomes of producing, distributing or receiving a text whether intended or foreseen or not" is located in the altered nature of my relationship to the musicians from the concert, the strengthening of our personal and musical friendships, and whatever other waves of meaning that Ascension set into motion through the community (Hanks 96).

I have suggested that theories of textuality which position readers in a more agentive relationship with texts are useful 
in locating and articulating aspects of musicians' experience in an improvised setting: in this sense, any improvised document has the capacity to yield similar results. But in a broader view, Ascension is not just any improvised document-it inscribes into sound, with unprecedented forcefulness, an energy that pulses today with a palpable urgency. It has become a gathering space for musicians to memorialize and articulate connections with Coltrane, and embed themselves along a historical continuum. As Daniel Fischlin and Ajay Heble comment, "the rising cacophony of horns" in Ascension is the sonic approximation of upward momentum, and "social and spiritual uplift, implied in both the music and its title" (Fischlin and Heble 26). In our group's reading of the work, improvisation is crucial to navigating and negotiating the textual logic of its narrative history. More importantly, it brings Ascension into dialogue with the original recording as not only a composition, but as a powerful vessel of communication and transformation across generations.

But since 2007, Ascension has evolved into a larger project for me-in the repeated performances and the unfolding ethnographic and self-reflexive inquiry over the past several years-that profiles a diachronic view of my involvement in Toronto's improvising music community. Not all of this has been especially positive. The fall 2008 performance in Guelph's eBar was a difficult experience- the sound was bad (the volume on stage was extremely loud, which compromised the performance for most of the ensemble); it was not well attended; and playing the piece in a rock club felt awkward. I found out long after that some musicians were dissatisfied with my organization of the event, and it effectively marked a closure of musical relations between myself and a few players. The performance in fall of 2012 at the MacDonald Stewart Art Centre at the University of Guelph was re-energizing, and again proved to be positive for several musicians, based on conversations that transpired following the show. Some of the musicians I hired had performed with me in 2007 and 2008, but half the ensemble consisted of new players I had since developed musical and professional relationships with in the intervening years. However, extreme tensions played out during the performance - which also escaped my attention-due to collisions of individual playing styles. I found out only afterwards from subsequent conversations with some musicians that they felt frustrated at the lack of communication among the ensemble. The result was an overall negative experience for them, and they intimated to me that they would be reticent to perform the work again. ${ }^{16}$

Indeed, as the foregoing analysis has shown, Ascension has proven to be a rich example where composition, improvisation, and socio-cultural contexts of making music expose their relationality, their mutual influence on each other, and how those vectors oscillate on a living, fluid continuum in the hands of new musicians. In performing the work, and evaluating the heterogeneity of experience as a case study which attests to the fundamental dialogism of textuality, the blurry relationships that in poststructural assertions position authors and readers-or composers and performers-in a dynamic balance become all the more clear. Its vitality and relevance to a new community of performers and listeners, however culturally and generationally disparate from its original social location, becomes reinvigorated anew. In the same way that Ingrid Monson asserts that performances assume the qualities of textuality in their recording and documentation, she recognizes their indispensability as resources for jazz musicians in a tradition whose repertoire and canon exist primarily as aural artifacts (126). I would add to this that recordings in turn are only one iteration of a text's interpretative and social life; one moment of rest in a cycle that, in this case, activated-and was reactivated by—a community of readers through the densely contoured pathways of improvisation and analysis.

\section{Notes}

${ }^{1}$ This performance, scheduled to take place outdoors as part of Guelph's inaugural Nuit Blanche, was cancelled due to inclement weather.

${ }^{2}$ The program, "Max Level," produced by Michael Aubin, aired May 9, 2013 on KJFC FM in Palo Alto, California. Other musicians interviewed for the special included Larry Ochs, Chris Brown, and Ikue Mori, who as part of "Orkestrova," presented an interpretation of Coltrane's piece they called "Electric Ascension" at the 2012 Guelph Jazz Festival.

${ }^{3}$ Other presentations of Ascension I have been able to locate, besides ROVA's ongoing concerts, include those by the Michael Eaton Large Large Ensemble (2006, Bloomington, Indiana), saxophonist Bobby Zankel (May 2012, Philadelphia), and the Matt Smiley Large Ensemble (October 2012, Denver, Colorado).

${ }^{4}$ Quoted from an interview with ROVA member Bruce Ackley: "As Glenn Spearman said, 'This is like our Handel's Messiah. We should do this every year.' We had that attitude about it. He said that we were going to go out there and do it" (Jung). 
${ }^{5}$ Barthes uses "Text" rather than "text" throughout the essay as a matter of style, and to preserve clarity in his argument. Text (rather than text) implies not only an Author-less and autonomous "field;" it also, for Barthes, performs a crucial act of distinguishing principal differences between the two. He writes that "the Text is radically symbolic: a work conceived, perceived and received in its integrally symbolic nature is a text. Thus is the Text restored to language; like language, it is structured but off-centred, without closure" (158-159).

${ }^{6}$ Transcriptions by the author.

${ }^{7}$ Kyle Brenders, who played alto saxophone in the concert, recorded the performance. All audio examples used are excerpted from that recording. Kyle's piece for large saxophone ensemble The Haphazard Hinges opened the concert. Interviews were conducted on 18 February 2008 (with Brodie West, Brandon Valdivia, and Mike Smith), 21 February 2008 (Jason Hay and John Kameel Farah), 28 February 2008 (Colin Fisher) and 4 March 2008 (Lina Allemano). Both Kyle and trumpeter Nick Buligan were unavailable when I requested to interview them in 2008.

${ }^{8}$ Colin's interview was conducted over the phone, and was not recorded; I am paraphrasing his comments based on my interview notes.

${ }^{9}$ The performance Brodie refers to can be seen here on YouTube: $\underline{h t t p: / / w w w . y o u t u b e . c o m / w a t c h ? ~} \mathrm{v}=\mathrm{sEN5nQfZSKQ}$

${ }^{10}$ Charles Hersch, in comparing Ascension to Ornette Coleman's earlier Free Jazz (1961) offers a similar analysis: "In the collective passages of Ascension, one has to strain to hear a particular instrumentalist. During the free improvisation sections, the players tend to repeat one phrase or simply 'scream' through their instruments (or pound away, in the drummer's case). Rather than a conversation, it is a collective religious ritual, an act of transcendence... One might call it 'textural' group improvisation rather than real polyphony" (116).

${ }^{11}$ See Franya J. Berkman's excellent article, "Appropriating Universality: the Coltranes and 1960s Spirituality," for a concise discussion on how and why Coltrane's "personalized, eclectic, and global" spiritualism resonated deeply with 1960s culture (45).

${ }^{12}$ As I listened to the recording, I picked out recurring motivic cells that some ensemble members played, but not all the time and not necessarily the same way. I indicated those modules on my "road map" for the musicians, and listed the four modal regions as cues. The cues essentially represented the only directions I gave for the ensemble sections, where the entire band is playing.

${ }^{13}$ Lina has extensive professional training, has done residencies in Banff and Alberta, regularly travels to New York City to perform there, and performs with top Canadian jazz ensembles. She has won many awards and merits, and has released several acclaimed records as leader of the Lina Allemano Four.

${ }^{14}$ Brodie was a late addition to the performance: one of the original alto players, Evan Shaw, had to withdraw from the concert just a few hours before due to a medical emergency. Brodie was already present for the gig to take part in The Haphazard Hinges, but he did not take part in the rehearsal for Ascension held a few days previous.

${ }^{15}$ See, for example, Schutz \& Luckmann for a brief discussion of the temporal organization events as subjectively experienced in inner time (52-56).

${ }^{16}$ Because consent forms were used only for the interviews conducted in 2008 , and due to the sensitive nature of some of these conversations, I am obligated to refrain from identifying musicians by name.

\section{Works Cited}

Ake, David. Jazz Matters: Sound, Place, and Time Since Bebop. Berkeley: U California P, 2010. Print.

Bailey, Derek. Improvisation: Its Nature and Practice in Music. 1980. United States: Da Capo, 1992. Print. 
Barthes, Roland. "From Work to Text." Image-Music-Text. Trans. Stephen Heath. New York: Hill and Wang, 1977. 155-64. Print.

Benson, Bruce Ellis. The Improvisation of Musical Dialogue: a Phenomenology of Music. Cambridge: Cambridge UP, 2003. Print.

Berkman, Franya J. "Appropriating Universality: the Coltranes and 1960s Spirituality." American Studies 48.1 (2007): 41-62. Print.

Berliner, Paul. Thinking in Jazz: the Infinite Art of Improvisation. Chicago: U Chicago P, 1994. Print.

Borgo, David. Sync or Swarm: Improvising Music in a Complex Age. New York: Continuum, 2005. Print.

---. "Synergy and Surrealestate: The Orderly Disorder of Free Improvisation." Pacific Review of Ethnomusicology 10 (2001/2002): 1-24. Print.

Corbett, John. "Ephemera Underscored: Writing Around Free Improvisation." Jazz Among the Discourses. Ed. Krin Gabbard. Durham: Duke UP, 1995. 217-242. Print.

Davis, Francis. Jazz and its Discontents: a Francis Davis Reader. Cambridge: Da Capo Press, 2004. Print.

Dessen, Michael. "Improvising in a Different Clave: Steve Coleman and AfroCuba de Matanzas." The Other Side of Nowhere: Jazz, Improvisation, and Communities in Dialogue. Middletown: Wesleyan UP, 2004. 173-194. Print.

Eagleton, Terry. Literary Theory: An Introduction. Oxford: Blackwell, 1992. Print.

Fischlin, Daniel and Ajay Heble. "The Other Side of Nowhere: Jazz, Improvisation, and Communities in Dialogue." The Other Side of Nowhere: Jazz, Improvisation, and Communities in Dialogue. Ed. Daniel Fischlin and Ajay Heble. Middletown: Wesleyan UP, 2004. 1-44. Print.

Gridley, Mark. "Misconceptions in Linking Free Jazz with the Civil Rights Movement." College Music Symposium 47 (2007): 139-155. Print.

Hanks, William F. "Text and Textuality." Annual Review of Anthropology 18 (1989): 95-127. Print.

Hersch, Charles. "Let Freedom Ring! Free Jazz and African American Politics." Cultural Critique 32 (1995-1996): 97123. Print.

Hogg, Bennett. "Enactive Consciousness, Intertextuality, and Musical Free Improvisation: Deconstructing Mythologies and Finding Connections." Music and Consciousness: Philosophical, Psychological, and Cultural Perspectives. Ed. David Clarke and Eric Clarke. Oxford: Oxford UP, 2011. 79-94. Print.

Jenkins, Willard. ROVA: “John Coltrane's Ascension (CD review).” Jazztimes.com. Oct.1997. Web. 14 May 2013.

Jones, Manina. "Textuality." Encyclopedia of Contemporary Literary Theory: Approaches, Scholars, Terms. Ed. Irena R. Makaryk. Toronto: U Toronto P, 1993. 641-2. Print.

Jost, Ekkehard. Free Jazz. Graz: Universal Editions, 1974. Print.

Jung, Fred. "Interview with Bruce Ackley." Rova.org. 11 Oct. 2002. Web. 15 May 2013.

Klein, Michael. Intertextuality in Western Art Music: Musical Meaning and Interpretation. Bloomington: Indiana UP, 2005. Print.

Kofsky, Frank. John Coltrane and the Jazz Revolution of the 1960s. New York: Pathfinder, 1998. Print. 
Kristeva, Julia. Desire in Language: a Semiotic Approach to Literature and Art. New York: Columbia UP, 1980. Print.

Medwin, Marc Howard. Listening in Double Time: Temporal Disunity and Structural Unity in the Music of John Coltrane 1965-67. Diss. University of North Carolina at Chapel Hill. Ann Arbor: UMI, 2008. Print.

Monson, Ingrid. Saying Something: Jazz Improvisation and Interaction. Chicago: U Chicago P, 1996. Print.

Nisensen, Eric. John Coltrane and his Quest. New York: St. Marten's Press, 1993. Print.

Porter, Lewis. John Coltrane: His Life and Music. Ann Arbor: U Michigan P, 1998. Print.

---. "Liner Notes." Coltrane, John. Ascension. Impulse! Records, 2000. CD.

Schutz, Alfred and Thomas Luckmann. The Structures of the Life World. Vol. 1. Trans. Richard M. Zaner and H. Tristram Engelhardt, Jr. Evanston: Northwestern UP, 1973. Print.

Singer, Milton. When a Great Tradition Modernizes: an Anthropological Approach to Modern Civilization. New York: Praeger, 1972. Print.

Such, David G. Avant-Garde Jazz Musicians: Performing “Out There.” lowa City: U lowa P, 1993. Print.

Titon, Jeff Todd. "Text." Eight Words for the Study of Expressive Culture. Ed. Burt Feintuch. Urbana: U Illinois P, 2003. 69-98. Print.

Thomas, Lorenzo. "Ascension: Music and the Black Arts Movement." Jazz Among the Discourses. Ed. Krin Gabbard. Durham: Duke UP, 1995. 256-74. Print. 